\title{
The Reef-fish Fauna of the Northern Patagonian Gulfs, Argentina, South- western Atlantic
}

\author{
David E. Galván ${ }^{*}$, Leonardo A. Venerus ${ }^{1}$ and Alejo J. Irigoyen ${ }^{1}$
}

Centro Nacional Patagónico (CONICET). Boulevard Brown 2825, (U9120ACF) Puerto Madryn, Chubut, Argentina

\begin{abstract}
A checklist containing 29 species of reef fishes recorded at the gulfs San José and Nuevo in Argentina ( 42 ${ }^{\circ}$ $\left.43^{\circ} \mathrm{S}\right)$ is provided. The reef-fish assemblages of the San José and Nuevo gulfs are a mix of warm-temperate fauna from the South-western Atlantic Province, and cold-temperate species from the South-American Province; however, warmtemperate fishes dominated in both gulfs. The presence of the families Bovichtidae, Eleginopidae, Nototheniidae, Congiopodidae, Sebastidae and Moridae distinguished the Patagonian region from the rest of the Atlantic coast.
\end{abstract}

Keywords: Reef-fish assemblages, Argentina, warm-temperate, cold-temperate, zoogeography.

\section{INTRODUCTION}

The Northern Patagonian gulfs of Argentina (Fig. 1) are located in the transition between two different biogeographic provinces [1-4]: the warm-temperate (WT) South-western Atlantic Province, with species typically ranging from Brazilian waters up to Northern Patagonia, and the coldtemperate (CT) South-American Province, with species typical of higher latitudes occurring up to the mouth of Río de la Plata. Thus the area has particular biogeographic relevance lying between two major provinces. In addition, both gulfs are cultural and economically important since each year hundred of thousands tourists from all over the world (350,000 visitors during 2007, DGEyC ${ }^{1}$ official statistics) arrive at Península Valdés for admiring its fauna and countryside. San José Gulf is the only Provincial Park in the Argentinean coast. The Península Valdés region, that includes the San José and Nuevo gulfs, was also designated an UNESCO Natural World Heritage Site in 1999. Defined as the "North Patagonian Gulfs Ecoregion", the coastal zone of Northern Patagonia has been assigned the highest conservation priority among other ecoregions in southern SouthAmerica [5], for its spectacular concentration of breeding sites for marine birds and mammals, but also for its heterogeneous collection of coastal habitats. Reef fishes also represent an attraction for recreational divers, and for sport anglers and spear-fishers [6]. Diving activity concentrates mainly in the shallow coastal waters near the village of Puerto Pirámide and the city of Puerto Madryn, considered the National Capital of Diving [7, 8].

*Address correspondence to this author at the Centro Nacional Patagónico (CONICET). Boulevard Brown 2915, (U9120ACF) Puerto Madryn, Chubut, Argentina; Tel: (+54) (2965) 45-1024/0401/1301; Fax: (+54) (2965) 451543; E-mail: galvan@cenpat.edu.ar

\footnotetext{
${ }^{1}$ Dirección General de Estadísticas y Censos de la Provincia de Chubut,
} http://www.estadistica.chubut.gov.ar/
Despite the scientific and cultural relevance of the Northern Patagonian reef-fish assemblages, their study has received little attention. There are only a handful of published studies that report the occurrence of particular and/or rare species on shallow rocky reefs within San José, Nuevo and San Matías gulfs (Pagrus pagrus Linné and Diplodus argenteus (Valenciennes): [9]; Mycteroperca marginata (Lowe): [10]; Seriola lalandi Valenciennes: [11]; and Pseudopercis numida Miranda-Ribeiro: [12]), and one study that describes the fish assemblage in one particular reef from San Matías Gulf [13]. Moreover, descriptions of the distributional ranges for Argentinean marine fishes were mainly based on individuals caught by trawling in the inner-shelf [1, 14-17], excluding shallow ( $<20 \mathrm{~m}$ depth) and rocky areas. Only the Beagle Channel $\left(\sim 55^{\circ} \mathrm{S}\right)$ fish assemblages have been described using sampling methods that were appropriate for reef fishes [18-20]. This constitutes a serious information gap in the ichthyological knowledge of South-America. For example, a recent published study on the biogeography of the reef fishes of the Atlantic Ocean [3] did not include the Patagonian fauna from Argentina due to the lack of specific published works about reef fishes for this region (S. R. Floeter, personal communication).

This study describes the reef-fish fauna of the San José and Nuevo gulfs in the South-western Atlantic. The reefs in these gulfs are small rocky patches, mainly rocky ledges $<100 \mathrm{~s} \mathrm{~m}$, that are scattered over extensive sandy, gravel and limestone bottoms $[21,22]$. Both gulfs are semi-enclosed areas, their maximum depths reach $70 \mathrm{~m}$ (San José Gulf) and $170 \mathrm{~m}$ (Nuevo Gulf), and their surface water temperature ranges between $8^{\circ} \mathrm{C}$ in August - September to $18^{\circ} \mathrm{C}$ in February - March (field records by the authors). To improve the knowledge about the fish assemblages from the Southwestern Atlantic we aimed (i) to inventory the reef fishes of the San José and Nuevo gulfs $\left(\sim 42^{\circ} S\right.$ to $\left.43^{\circ} \mathrm{S}\right)$, including when possible abundance data; and (ii) to compare the zoogeographical affinities of this reef-fish fauna with that occurring in San Matías Gulf $\left(\sim 40^{\circ} 30^{\prime}\right.$ S $)$ to the north, and that to the south, as far as San Jorge Gulf $\left(\sim 46^{\circ} \mathrm{S}\right)$. 


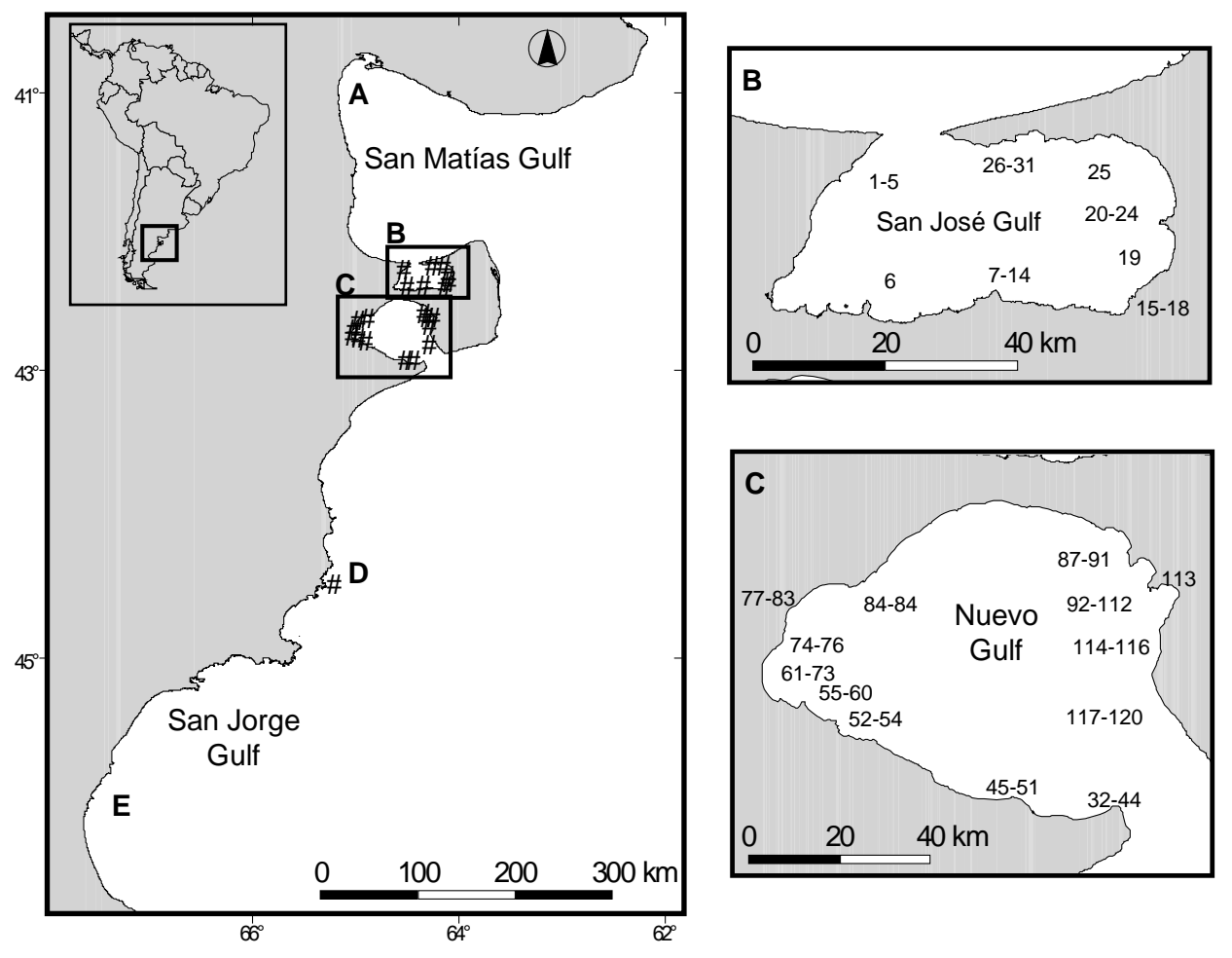

Fig. (1). Map of the study area showing sampling sites. Letters identify sites, circles indicate areas where one or more reefs were visited and numbers identify the sampled reefs from San José and Nuevo gulfs. A = San Matías Gulf; B = San José Gulf; C = Nuevo Gulf; D = Cabo Raso and E = San Jorge Gulf. Reefs 15, 19, 26-28, 55-56, 61-64, 74 and 92-95 were monitored to describe the temporal dynamics of the reef fish assemblages. Reefs 7-9, 15-19, 26-30, 45-49, 53-56, 74, and 91-98 were used to describe the relationship among reef fish assemblages and the features of the reefs. In the other reefs solely exploratory surveys were conducted.

\section{MATERIAL AND METHODS}

In this study the term 'reef fish' was used to include a fish primarily associated and dependant on hard substratum or its immediate vicinity for refuge and feeding during any phase of post-settlement life; the term also include epipelagic species that visit the reefs to forage or reproduce [23]. The species included in the list came from specimens observed or collected by the authors, photographed by scuba divers or caught by spear-fishers or anglers in rocky areas. Sightings of fishes were recorded by the authors during quantitative visual censuses or during exploratory census surveys on reefs up to $30 \mathrm{~m}$ depth. Exploratory surveys were conducted between 1998 and 2008 and covered 120 different reefs. Sixteen of these reefs were also monitored by visual censuses on a monthly or a bimonthly basis over at least two years, depending on site accessibility, to describe the temporal dynamics of the assemblages. In addition, on thirty-one reefs, visual censuses were conducted to describe the relationship among the reef-fish assemblages and the physical and biological features of the reefs (Fig. 1). For a detailed description of the census methodologies see [24-26]. Fishes smaller than $10 \mathrm{~cm}$ total length and species of the families Agonidae, Clinidae, Tripterygidae and Batrachoididae were excluded from quantitative visual censuses because of their cryptic behaviour and/or small size (see [27]). However, during the exploratory surveys, all fishes sighted were recorded, including those found when inspecting holes and crevices. Collection of specimens for identification purposes took place dur- ing routine biological sampling on spear-fishing tournaments in Nuevo Gulf and angling captures in San José Gulf since 2002. In addition, several divers, spear-fishers and anglers contributed to the list by reporting their captures or photographing the rare species. These reports were confirmed only after one of the authors had analyzed the specimens or their photographs in the laboratory. Fishes were listed following [28] and the revised classification of the Serranidae [29, 30], and revised status of the species of Acanthistius (Gill) [31] were adopted.

The qualitative scale used by [23] to report the abundance of fishes was adopted: abundant $=$ sightings of many individuals expected on nearly every dive; very common = sightings expected on nearly every dive, but of few individuals; common $=$ sights frequent, but not necessarily expected on every dive; occasional $=$ sightings not unusual, but not expected on a regular basis; unusual = sighting occurs less than occasionally; and rare $=$ sights exceptional. Seasonal changes in the abundances of fishes were reported only for those species recorded during the visual census surveys, categorized as abundant, very common or common. Less frequent fishes did not allow any trends in abundance to be detected. To report these seasonal patterns a qualitative scale was defined: strong $=$ abundance varied $\geq 30 \%$ throughout the annual cycle; weak $=$ abundance varied $<30 \%$ throughout the annual cycle; and no pattern $=$ no clear or predictable seasonal pattern observed. 
Table 1. Families and Species of Reef Fishes Recorded in the San José and Nuevo Gulfs, Including Geographic Affinity, Abundance, Seasonal Pattern and Type of Record

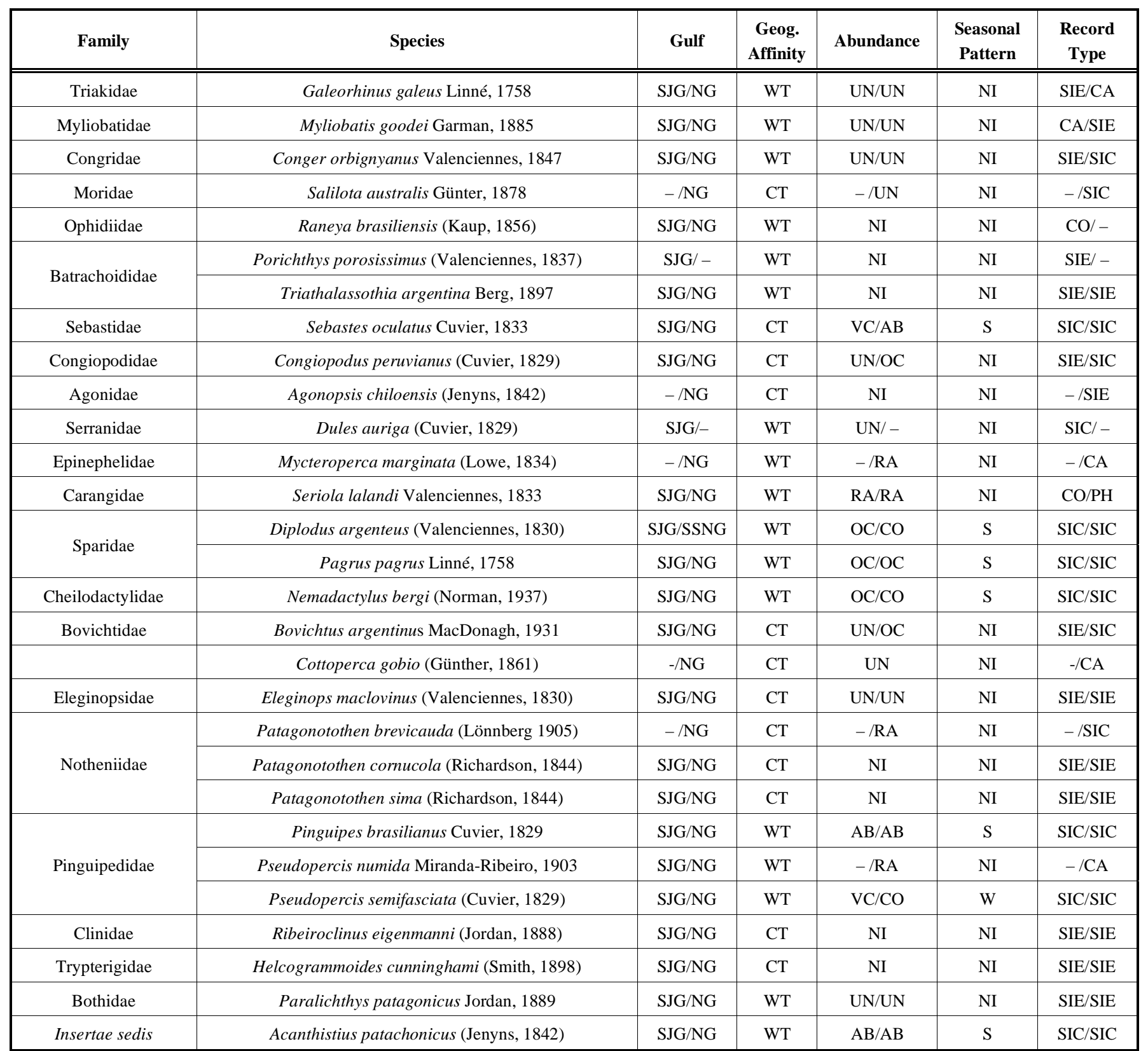

Families were arranged following [28]; genera and species were arranged in alphabetical order. Gulfs: GSJ = San José and GN = Nuevo. Geographical affinity: WT = warmtemperate (Southwestern Atlantic Province) and $\mathrm{CT}=$ cold-temperate (South-American Province). Abundance categories: $\mathrm{AB}=\mathrm{Abundant} ; \mathrm{VC}=\mathrm{Very}$ common; $\mathrm{CO}=\mathrm{Common} ; \mathrm{OC}$ = Occasional; RA = Rare and UN = Unusual. Seasonal pattern categories: $\mathrm{S}=$ Strong; $\mathrm{W}=$ Weak and NI = species not recorded during visual censuses, Record Type: $\mathrm{CA}=$ Caught; $\mathrm{CO}=$ Collected; $\mathrm{PH}=$ Photograph $; \mathrm{SIC}=$ Sighting during visual censuses and SIE $=$ Sighting during exploratory surveys .

Latitudinal comparisons on the assemblages composition were based on the species recorded during visual censuses from three reefs in San Matías Gulf (40 40'S), ten in San José Gulf $\left(42^{\circ} 13^{\prime}-42^{\circ} 26^{\prime} S\right)$, 20 in Nuevo Gulf (42 $30^{\prime}$ $\left.43^{\circ} 00^{\prime} \mathrm{S}\right)$, three in Cabo Raso $\left(44^{\circ} 35^{\prime} \mathrm{S}\right)$ and one reef in San Jorge Gulf ( $\left.45^{\circ} 50^{\prime} S\right)$. In order to minimize the differences in sampling effort among sites (i.e. "low sampling-effort sites": San Matías and San Jorge gulfs, and Cabo Raso; "high sampling-effort sites": San José and Nuevo gulfs), comparisons were done including all the species recorded in low sampling-effort sites but only the species classified as occasional, common and very common in high sampling-effort sites. Zoogeographical affinities of the species were determined following known biogeography $[1,4,14,16]$ and catalogues or species lists that include their geographical distribution or occurrence sites [15, 17, 19, 32-40].

\section{RESULTS}

Twenty-nine species in 26 genera and 21 families were recorded; 22 species were present in both gulfs, two species being found exclusively in San José Gulf and the other five only occurring in Nuevo Gulf (Table 1). Nototheniidae and Pinguipedidae were the two most important families, repre- 


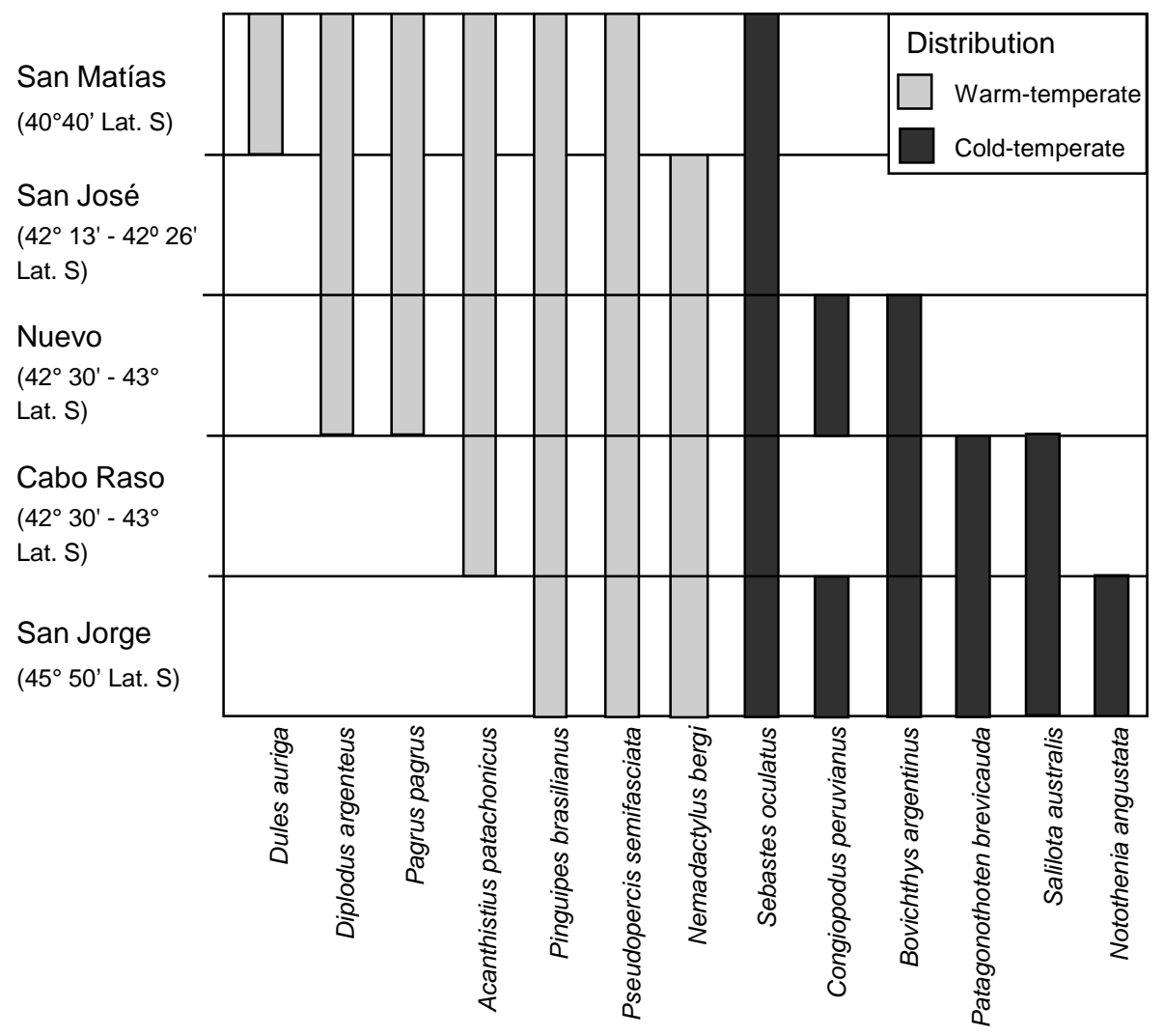

Fig. (2). Species recorded by visual censuses. Filled bars indicate sightings of each species in those sites. Only fishes sighted occasionally or more frequently in San José and Nuevo gulfs were included.

sented by three species each; and the genera Patagonotothen and Pseudopercis were the most important genera, with three and two species, respectively. However $P$. numida was represented by only one fish speared in Nuevo Gulf [12].

Overall, 17 species ( $58 \%$ of the total) were classified as WT species and 12 (42\%) as CT species (Table 1). Considering all fishes recorded in each gulf, $67 \%$ of the species from San José Gulf were WT, and 33\% were CT, while in Nuevo Gulf these percentages were $55 \%$ and $45 \%$, respectively (Table 1). Warm-temperate species were also the dominant fauna among the occasional or more abundant species (Table $\mathbf{1}$ and Figs. 2 and 3): six of seven species (87\%) in San José Gulf and six of nine species $(67 \%)$ in Nuevo Gulf. Fishes recorded to the north, within San Matías Gulf, included the most conspicuous fauna from San José Gulf (Fig. 2). A gradual substitution of warm-temperate by cold-temperate components was evident in the assemblages from San Matías Gulf to San Jorge Gulf. In San Matías Gulf only WT species were present, in Cabo Raso four species of each group were recorded, while in San Jorge Gulf three fishes were WT and the other six were CT (Fig. 2).

\section{DISCUSSION}

The Northern Patagonia rocky reefs from Argentina are occupied by species belonging to two zoogeographical provinces, and characterize by low species richness, 29 fishes in San José and Nuevo gulfs, compared with other reef-fish assemblages from lower latitudes in the Western Atlantic (Table 2).
Warm-temperate fauna dominated both gulfs. Unexpected was the occurrence of $P$. numida $c$. $1600 \mathrm{~km}$ southwards of its previously reported limit (widely discussed in [12]). The lists of fishes from San Matías Gulf, Cabo Raso and San Jorge Gulf are incomplete descriptions of the reef fish assemblages from those sites. For example, Congiopodus peruvianus (Cuvier) was not recorded in Cabo Raso, however this species could be present and be quite common there (suggested by the results showed in Fig. 2). Visual censuses are needed on a greater number of reefs and/or other sources of information for each site are required, as we have done for the San José and Nuevo gulfs. The present lists have nevertheless been useful for making latitudinal comparisons among the most conspicuous coastal reef fishes.

The distributional patterns of the most conspicuous WT species between San Matías and San Jorge gulfs coincided with the expected ranges based on previous biogeographic data $[1,4,14,16]$ and catalogues of fishes [17, 19, 36, 39] for the Argentinean coast. However, the number of CT species recorded to the north of San Jorge Gulf was lower than expected. For example, the presence of Salitota australis Günther had been cited up to $\sim 40^{\circ} \mathrm{S}$ [18] (Fig. 4) but we did not record it north of Nuevo Gulf (42³0'S) (Fig. 2). This difference could be explained by a progressive displacement of CT species to deeper and less coastal waters with decreasing latitude from Cabo Raso [1,4]. Inshore waters along the Argentine Sea are usually warmer and host warmer-water organisms than those further offshore at the same latitudes [2]. Thus the CT fish fauna could be associated with colder 
Table 2. Species Richness Reported for the Western Atlantic

\begin{tabular}{|c|c|c|c|}
\hline Bermudas, Caribbean & $32^{\circ} \mathrm{N}$ & 281 & {$[42]++$} \\
\hline Mona Passage, Caribbean & $18^{\circ} \mathrm{N}$ & 261 & {$[44]+$} \\
\hline Bocas, Caribbean & $9^{\circ} \mathrm{N}$ & 97 & {$[45]^{*}$} \\
\hline Atol de Rocas & $4^{\circ} \mathrm{S}$ & 103 & {$[42]++$} \\
\hline St. Paul Rocks, North Brazil & $1^{\circ} \mathrm{S}$ & 54 & {$[42]++$} \\
\hline Parcel Manual Luiz, North Brazil & $1^{\circ} \mathrm{S}$ & 132 & {$[46]^{* *}$} \\
\hline Guarapari Island, South Brazil & $20^{\circ} \mathrm{S}$ & $81 / 270$ & {$[45]^{* /[}[42]++$} \\
\hline Trinidad Island, South Brazil & $21^{\circ} \mathrm{S}$ & 87 & {$[42]++$} \\
\hline Carragas, South Brazil & $23^{\circ} \mathrm{S}$ & 99 & {$[48]^{*}$} \\
\hline Arraial do Cabo, South Brazil & $23^{\circ} \mathrm{S}$ & 257 & {$[42]++$} \\
\hline Ilha Grande, South Brazil & $23^{\circ} \mathrm{S}$ & 243 & {$[42]++$} \\
\hline Laje de Santos, South Brazil & $24^{\circ} \mathrm{S}$ & 196 & {$[23]^{* *}$} \\
\hline Arvoredo, South Brazil & $27^{\circ} \mathrm{S}$ & $67 / 195$ & {$[45]^{* /[42]++}$} \\
\hline
\end{tabular}

One asterisk identifies those studies where the number of species resulted from fishes observed during visual censuses without considering other sources of information. Two asterisks identify the studies where the number of species resulted from fishes observed, photographed, and/or collected.+: rotenone surveys plus museums collections. ++: number of species compiled by [42], only sites of similar or smaller area than the Northern Patagonian gulfs were included (for details see Table A1 [42]).

and denser water masses, under the influence of the Malvinas current, which flows under the warmer Brazil current water [2]. Similarly, CT crustaceans also show a progressively deeper distribution northwards $43^{\circ}-45^{\circ} \mathrm{S}$ [41]. The species classified in this study as WT fishes had been included [16] in the "inner shelf mixed fauna" (Acanthistius patachonicus (Jenyns), Pinguipes brasilianus Cuvier, $P$. semifasciata (Cuvier), Nemadactylus bergi (Norman) and Paralichthys patagonicus (Jordan)) or "Bonaerensean fauna" (P. pagrus, Triathalassothia argentina Berg, Porichthys porosissimus (Valenciennes) and Conger orbignyanus Valenciennes); while those classified by us as CT reef fishes, had been assigned to the "widely distributed species" (S. australis and C. peruvianus), "rare species" (Sebastes oculatus Cuvier) or "the main Magellanic fauna" (Eleginops maclovinus (Valenciennes)) [16]. In corroboration of the bathymetric segregation between WT and CT faunas, those species classified as "widely distributed species", "rare species" or "the main Magellanic fauna" were recorder [16] at greater depths than those classified as "inner shelf mixed fauna" and "Bonaerensean fauna" (Fig. 4). The database [16] however lacked of one thorough sample on the coastal area south of $43^{\circ} \mathrm{S}$ and depths $<20 \mathrm{~m}$, that has now been achieved, and was based exclusively on trawling captures. This would explain the absence of coastal species in the data set [16], such as Dules auriga (Cuvier), D. argenteus (Valenncienes), Notothenia angustata (Hutton) and Bovichtus argentinus (MacDonagh), or the extremely low number of S. oculatus, the last being classified as a rare species.

The coastal reef ichthyofauna of the Argentine province, from the mouth of Río de la Plata $\left(\sim 36^{\circ} \mathrm{S}\right)$ to Northern Patagonia, was clustered with the South-western Atlantic province, from Bahia $\left(\sim 14{ }^{\circ} \mathrm{S}\right)$ to Santa Catarina, $\left(\sim 28^{\circ} \mathrm{S}\right)$ (see Fig. 4 in [3]), being the Argentine province a lesserdiversity area. One of the characteristics shared by both areas and that was considered to differentiate them from the rest of the Atlantic reef faunas is the importance of the family Pinguipedidae in terms of number of species [3]. However, there is not any information on the taxonomical features that differentiate the reef fish fauna southward Peninsula Valdés from the rest of the Atlantic reef-fish fauna. The present paper shows that to the south of $\sim 40^{\circ}-41^{\circ} \mathrm{S}$ the Brazilian reef ichthyofauna is progressively replaced by CT species belonging to nine families (Table 1), six of them (Bovichtidae, Eleginopidae, Nototheniidae, Congiopodidae, Sebastidae, and Moridae) being absent along the Atlantic coastal reefs to the north of Patagonia (see the analyses of species by family presented in Fig. (2) in [3]). The presence of these six fami- 


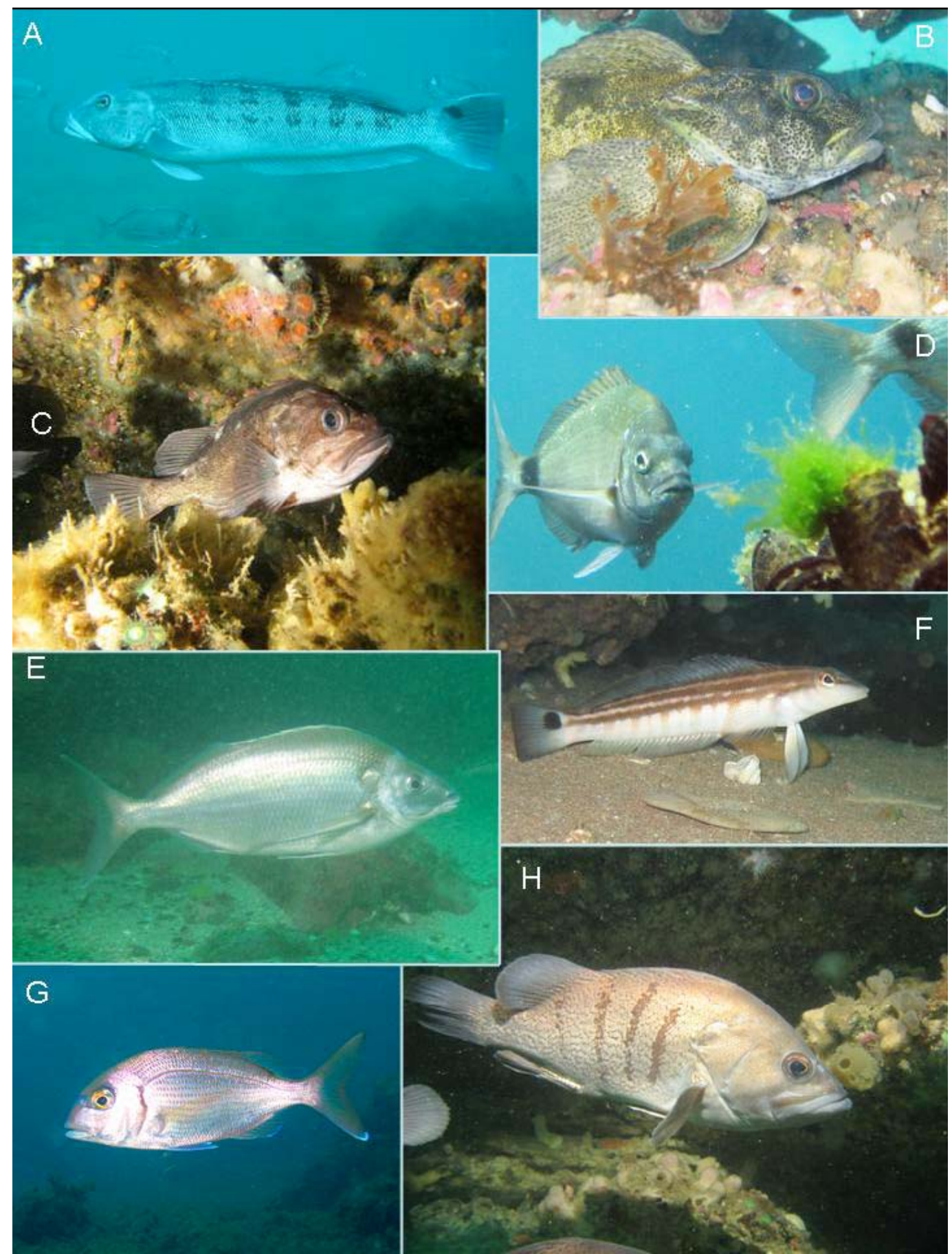

Fig. (3). Some reef fishes observed in the Northern Patagonian gulfs of Argentina. (A) Pseudopercis semifasciata; (B) Bovichtus argentinus; (C) Sebastes oculatus; (D) Diplodus argenteus; (E) Nemadactylus bergi; (F) Pinguipes brasilianus; (G) Pagrus pagrus and (H) Acanthistius patachonicus. Photos: AJI, except (g) by A. Carvalho-Filho.

lies biogeographically distinguishes the Patagonian region from the rest of the Atlantic coast.

This paper constitutes the first checklist of fishes associated with reefs in Argentina, and it fills a major gap in the knowledge of the South-western Atlantic ichthyofauna.

\section{APPENDIX}

Collection vouchers of specimens from San José and Nuevo gulfs collected by the authors. All the specimens were deposited in the ichthyological collection of the Centro Nacional Patagónico (CNPICT). Species are arranged in alphabetical order. Bovichtus argentinus - CNPICT 2003/63, 2007/7; Helcogrammoides cunninghami - CNPICT 2003/66; Mycteroperca marginata - CNPICT 2004/29; Nemadactylus bergi - CNPICT 2007/5; Pagrus pagrus CNPICT 2003/5-2, 2003/4, 2004/4; Patagonotothen brevicauda - CNPICT 1998/1, 1998/3; Patagonotothen cornucola - CNPICT 2003/67; Patagonotothen sima - CNPICT 1995/53, 2003/13; Pseudopercis numida - CNPICT 


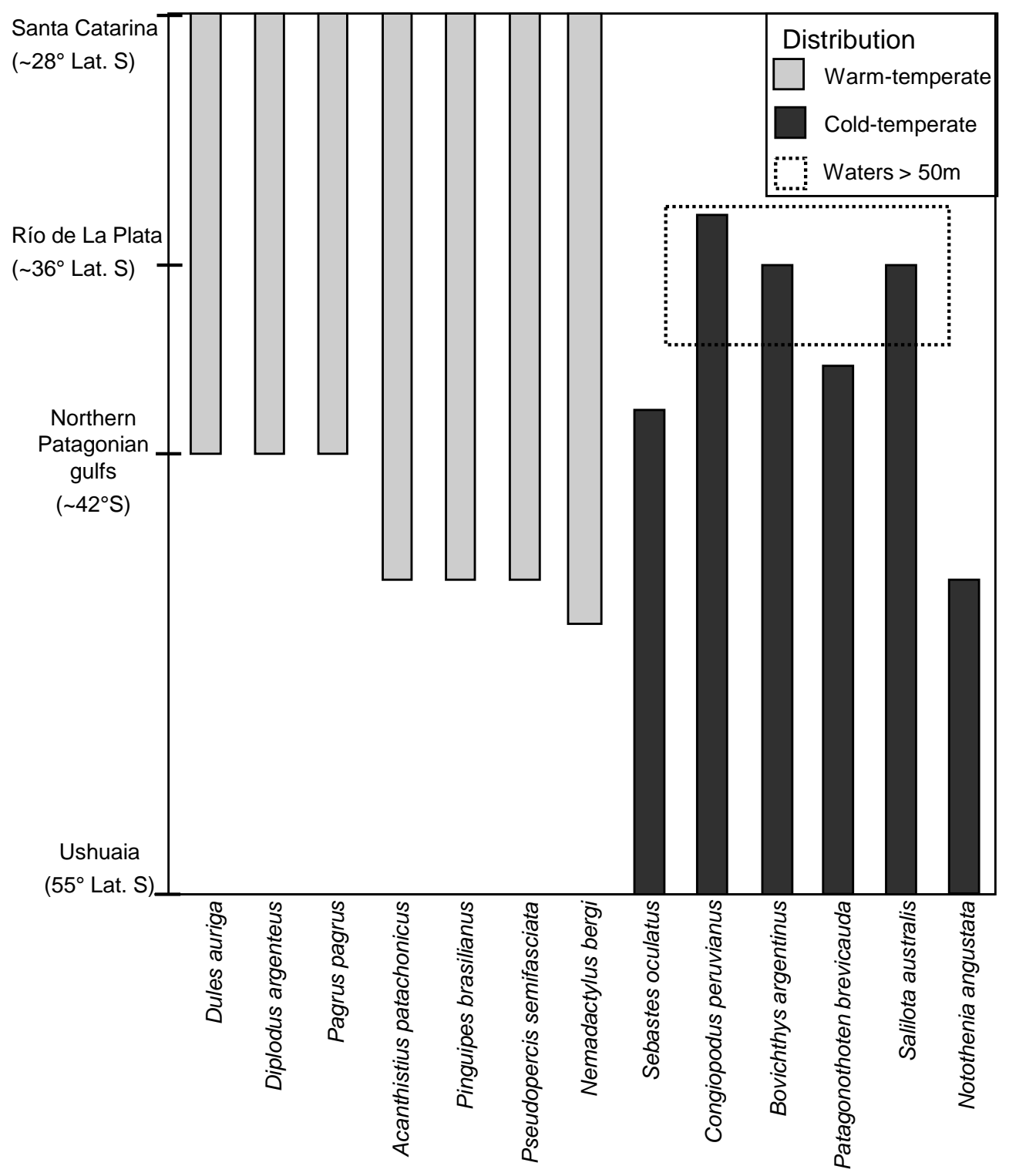

Fig. (4). Species ranges according with references [1, 14-17, 19, 32-40]. Filled bars indicate that the species occurred within the latitudes. The species included are the same that in Fig. (2). The doted-line frame indicates that the species inside occurs in waters $>50 \mathrm{~m}$.

2005/2; Raneya brasiliensis - CNPICT 2007/4; Sebastes oculatus — CNPICT 1999/4, 2004/1.

\section{ACKNOWLEDGEMENTS}

We thank many technicians, divers, spear-fishers and anglers for their valuable help in the field and for sharing their knowledge with us: Gringo Durbas, F. Quiroga, M. Cuestas, G. Pérez, de Francescos, P. Fiorda, A. Kowalyk, L. Loto, H. Díaz, R. Vera, and N. Ortíz. We also thank those responsible for the ichthyological collection of the Centro Nacional Patagónico, A. E. Gosztonyi, L. Kuba, L. Mansur and M. Nilsson. Comments of an anonymous reviewer and of $\mathrm{N}$. Polunin (Newcastle University - School of Marine Science and Technology) greatly improved the manuscript. The authors were supported by the Consejo Nacional de Investigaciones Científicas y Técnicas (CONICET). This work was financed by grants from the Agencia Nacional de Promoción
Científica y Tecnológica (PICT 10041), PADI Foundation and Wildlife Conservation Society (WCS 34320). AJI used an underwater camera provided by Idea Wild. Fieldwork was partially conducted within a World Natural Heritage Site and the project was approved by the Dirección General de Conservación de Areas Protegidas del Chubut.

\section{ABBREVIATIONS}

$\begin{array}{lll}\mathrm{CT} & = & \text { cold-temperate } \\ \mathrm{WT} & = & \text { warm-temperate }\end{array}$

\section{REFERENCES}

[1] López RB. Problems in the geographic distribution of the SouthAmerican marine fishes. Bol Inst Biol Mar 1964; 7: 57-62.

[2] Boltovskoy D, Gibbons MJ, Hutchings L, Binet D. In: Boltovskoy D, Ed. South Atlantic Zooplankton. Leiden: Backhuys Publishers 1999; pp. 1-42. 
[3] Floeter SR, Rocha LA, Robertson DR, et al. Atlantic reef fish biogeography and Evolution. J Biogeog 2008; 35: 22-47.

[4] Balech E, Erlich M. Biogeographic scheme of the Argentine Sea. Rev Investig Desarr Pesq 2008; 19: 45-75.

[5] Sullivan K, Bustamante G. Setting geographic priorities for marine conservation in Latin America and the Caribbean. Virginia: The Nature Conservancy 1999.

[6] Venerus LA. Spatial dynamics of the Argentine sandperch Pseudopercis semifasciata (Cuvier, 1829) (Pinguipedidae) - Implications for the sustainable use of rocky reef systems. Doctoral Thesis: Buenos Aires; Universidad de Buenos Aires 2006.

[7] Pérez Serra J. Underwater stories. Diving in the 1960s. Buenos Aires: Travesía Ediciones 1996.

[8] Sanabra F. Diving into memories. Puerto Madryn: Ocean Ediciones Submarinas 2002.

[9] Galván DE, Venerus LA, Irigoyen AJ, Parma AM, Gosztonyi AE. Extension of the distributional range of the silver porgy, Diplodus argenteus (Valenciennes 1830), and the red porgy, Pagrus pagrus (Linnaeus 1758) (Sparidae) in northern Patagonia, south-western Atlantic. J Appl Ichthyol 2005; 21: 444-7.

[10] Irigoyen AJ, Galván DE, Venerus LA. Occurrence of dusky grouper Epinephelus marginatus (Lowe, 1834) in gulfs of northern Patagonia, Argentina. J Fish Biol 2005; 67: 1741-45.

[11] Irigoyen AJ, Galván DE, Venerus LA. Occurrence of two warmtemperate fishes, Epinephelus marginatus (Lowe 1834) and Seriola lalandi Valenciennes 1833, in Northern Patagonian gulfs. In: Boschi EE, Bremen CS, Cousseau MB, Elías R, Roux AM, Eds. V Jornadas Nacionales de Ciencias del Mar; 2003: Mar del Plata, INIDEP and UNMdP 2003; p. 123.

[12] Venerus LA, Galván DE, Irigoyen AJ, Gosztonyi AE. First record of the namorado sandperch, Pseudopercis numida MirandaRibeiro, 1903 (Pinguipedidae; Osteichthyies) in Argentine waters. J Appl Ichthyol 2007; 23: 110-2.

[13] González RA. Translated title: Variations in the abundance of fishes along the annual cycle, in a Northern Patagonian subtidal rocky reef. In: Caille G, Crespo EA, Esteves JL, Koen Alonso M, Eds. Actas de las Jornadas Nacionales de Ciencias del Mar; 1991: Puerto Madryn, CENPAT and UNPSJB 1993; pp. 118-28.

[14] Menni RC, Gosztonyi AE. Benthic and semidemersal fish associations in the Argentine Sea. Stud Neotrop Fauna Environ 1982; 17 : $1-29$.

[15] Otero H, Bezzi S, Renzi M, Verazay G. Atlas of the demersal fisheries resources of the Argentine Sea. Mar del Plata; INIDEP 1982.

[16] Menni RC, López HL. Distributional patterns of Argentine marine fishes. Phys Sec A 1984; 42: 71-85.

[17] Cousseau MB, Perrotta RG. Argentinean marine fishes: biology, distribution and fisheries. Mar del Plata: INIDEP 2000.

[18] Lloris D, Rucabado J. Ichthyofauna of the Beagle Channel (Tierra del Fuego), ecological and biogeographical issues. Madrid: Publicaciones Especiales del Instituto Español de Oceanografía 1991.

[19] López HL, García M, San Román N. Annotated checklist of the Beagle Channel ichthyofauna. Contribución Científica Especial. Tierra del Fuego: CADIC 1996.

[20] Vanella FA, Fernández DA, Romero MC, Calvo J. Changes in the fish fauna associated with a sub-Antarctic Macrocystis pyrifera kelp forest in response to canopy removal. Polar Biol 2007; 30: 449-57.

[21] Ciocco N. Observations on the ecology of the bivalve Chlamys tehuelchus (d'Orb.) in the San José Gulf (Chubut, Argentina). Geotrópica 1988; 34: 3-22.

[22] Parker G, Paterlini MC, Violante MA. Marine bottoms. In: Boschi EE, Ed. The Argentine Sea and its fisheries resources, Section 1. Mar del Plata: INIDEP 1997; pp. 65-88.

[23] Luiz Jr. OJ, Carvalho-Filho A, Ferreira CEL, Floeter SR, Gasparini JL, Sazima I. The reef fish assemblage of the Laje de Santos Marine State Park, Southwestern Atlantic: annotated checklist with comments on abundance, distribution, trophic structure, symbiotic associations, and conservation. Zootaxa 2008; 1807: 1-25.

[24] Galván DE. Fish assemblages of the Northern Patagonian reefs: diversity, abundance, trophic relationships and associations with the habitat. Doctoral Thesis: Bariloche; Universidad Nacional del Comahue 2008.
[25] Venerus LA, Parma AM, Galván DE. Annual occupation pattern of temperate rocky reefs by the Argentine sandperch Pseudopercis semifasciata in San José Gulf Marine Park, Argentina. Fish Manag Ecol 2008; 15: 217-29.

[26] Irigoyen AJ. Temporal and spatial distribution of the Argentine sea bass (Acanthistius brasilianus) in the Argentine Sea. Bachelor Thesis: Puerto Madryn; Universidad Nacional de la Patagonia 2006.

[27] Willis TJ. Visual census methods underestimate density and diversity of cryptic reef fishes. J Fish Biol 2001; 59: 1408-11.

[28] Eschmeyer WN, Fong JD. Species of Fishes by family/subfamily [homepage on the Internet]. California: California Academy of Sciences, 2008 Apr 23, cited 2008 Oct 17]. Available from: http://research.calacademy.org/research/ichthyology/catalog/Specie sByFamily.asp [cited: 17 Oct 2008].

[29] Craig MT, Hastings PA. A molecular phylogeny of the groupers of the subfamily Epinephelinae (Serranidae) with a revised classification of Epinephelini. Ichthyol Res 2007; 54: 1-17.

[30] Smith WL, Craig MT. Casting the Percomorph net widely: the importance of broad taxonomic sampling in the search for the placement of the serranid and percid fishes. Copeia 2007; 1: 35-55.

[31] Irigoyen AJ, Gerhandinger LC, Carvalho-Filho A. On the status of the species of Acanthistius (Gill, 1862) (Percoidei) in the SouthWest Atlantic Ocean. Zootaxa 2008; 1813: 51-9.

[32] Figueiredo JL. Handbook of marine fishes from the South-eastern Brazil. I. Sharks, rays and chimeras. São Pablo: Museu de Zoologia Universidade do São Paulo 1977.

[33] Figueiredo JL, Menezes NA. Handbook of marine fishes from the South-eastern Brazil. II. Teleostei (1). São Pablo: Museu de Zoologia Universidade do São Paulo 1978.

[34] Figueiredo JL, Menezes NA. Handbook of marine fishes from the south-eastern Brazil. III. Teleostei (2). São Pablo: Museu de Zoologia Universidade do São Paulo 1980.

[35] Figueiredo JL, Menezes NA. Handbook of marine fishes from the south-eastern Brazil. VI. Teleostei (5). São Pablo: Museu de Zoologia Universidade do São Paulo 2000.

[36] Gosztonyi AE. Results of the ichthyological investigations during Survey I of the B/I "Shinkai Maru" in the Argentine Sea. (10.0409.05.1978). Contribución INIDEP 1981; 383: 254-66.

[37] Menezes NA, Figueiredo JL. Handbook of marine fishes from the south-eastern Brazil. IV. Teleostei (3). São Pablo: Museu de Zoologia Universidade do São Paulo 1980.

[38] Menezes NA, Figueiredo JL. Handbook of marine fishes from the south-eastern Brazil. V. Teleostei (4). São Pablo: Museu de Zoologia Universidade do São Paulo 1985.

[39] Menni RC, López HL, García ML. Annotated checklist of the fishes collected by B/I "Shinkai Maru" during Survey V in the Argentine Sea (25.08-15.09.1978). Contribución INIDEP 1981; 383: 255-80.

[40] Froese R, Pauly D. FishBase [homepage on the Internet]. Makati: FishBase, updated. Available from: www.fishbase.org [cited: 17 Oct 2008].

[41] Boschi EE, Fischbach CE, Iorio MI. Illustrated handbook of marine stomatopods and decapods of Argentina. Frente Marít 1992; 10: 194.

[42] Halpern BS, Floeter SR. Functional diversity responces to changing species richness in reef fish communities. Mar Ecol Prog Ser 2008; $364: 147-56$.

[43] Jordan LKB, Gillian DS, Spieler RE. Reef fish assemblage structure affected by small-scale spacing and size variations of artificial patch reefs. J Exp Mar Biol Ecol 2005; 326: 170-86.

[44] Dennis GD, Smith-Vaniz WF, Colin PL, Hensley DA, McGehee MA. Shore Fishes from Island of the Mona Passage, Greater Antilles with Comments on heir Zoogeography. Caribb J Sci 2005; 41: 716-43.

[45] Floeter SR, Ferreira CEL, Dominici-Arosemena A, Zalmon I. Latitudinal gradients in Atlantic reef fish communities: trophic structure and spatial use patterns. J Fish Biol 2004; 64: 1680-99.

[46] Rangel CA, Chaves LCT, Monteiro-Neto C. Baseline assessment of the reef fish assemblage from Cagarras Archipelago, Rio de Janeiro, Southeastern Brazil. Braz J Oceanog 2007; 55: 7-17.

[47] Rocha LA, Rosa IL. Baseline assessment of reef fish assemblages of Parcel Manuel Luiz Marine State Park, Maranha o, north-east Brazil. J Fish Biol 2001; 58: 985-98. 
[48] de Souza AT, di Iulio Ilarri M, de Medeiros PR, Grotta Grempel R, Rosa RS, Sampaio CLS. Fishes (Elasmobranchii and Actinoptery- gii) of Picãozinho reef, Northeastern Brazil, with notes on their conservation status. Zootaxa 2007; 1608: 11-9.

Received: November 30, 2008

Revised: August 13, 2009

Accepted: November 13, 2009

(C) Galván et al.; Licensee Bentham Open.

This is an open access article licensed under the terms of the Creative Commons Attribution Non-Commercial License (http://creativecommons.org/licenses/by-nc/3.0/) which permits unrestricted, non-commercial use, distribution and reproduction in any medium, provided the work is properly cited. 